\title{
Physical and rheological properties of the Chorfa dam mud: dependency on solids concentration
}

\author{
Abderrahmane Messaoudi $^{1} \cdot$ Mohamed Bouzit $^{1} \cdot$ Nabila Boualla $^{2}$ (D)
}

Received: 22 July 2018 / Accepted: 11 September 2018 / Published online: 25 September 2018

(c) The Author(s) 2018

\begin{abstract}
The main purpose of this study is to determine the mud rheological properties of the Chorfa dam (region of Mascara, Algeria) and to propose a rheological model that describes mud flow behavior. This study helps on one hand to give a better understanding of fine sediment transport dynamics in the dam, as well as contributing to reduce the dredging costs, and on other hand to valorize dredged sediments in road construction. Rheological measurements were conducted using an Engler viscometer and a Haake RS 600 rheometer. Mud samples were prepared with purified water at a range of solids concentration varying between 5.0 and 32.5\%. Besides, the physical, chemical and mineralogical characteristics of the Chorfa dam's mud and the rheological tests were presented and the effect of solids concentration on mud viscosity was studied. The results indicate that the Chorfa dam's mud showed a non-Newtonian behavior for solids concentration higher than the critical solids concentration, and the apparent viscosity increases with increasing solid concentration at different shear rates. In addition, for a fixed concentration, the apparent viscosity decreases with increasing shear rates, which approves the shear thinning behavior of the Chorfa dam's mud. Fitting results of four rheological models (Bingham Plastic Model, Ostwald-de Waele (power law), Herschel-Bulkley and Casson) to the experimental data were presented. Hence, the Ostwald-de Waele model was the best fitting model for mud samples.
\end{abstract}

Keywords Mud $\cdot$ Solids concentration $\cdot$ Apparent viscosity $\cdot$ Rheometer $\cdot$ Rheological model

\section{Introduction}

The siltation is a rather great problem for many dams in the world. In Algeria, the phenomenon of siltation includes most dams where more than 32 million $\mathrm{m}^{3}$ of sediments settle every year in the bottom of these reservoirs (Remini and Avenard 1998) which reduce dam water storage capacity and pose a risk to the dam's stability. For example, the

Abderrahmane Messaoudi

messaoudi_a@yahoo.fr

Mohamed Bouzit

bouzit_mohamed@yahoo.fr

Nabila Boualla

nibrasnabila@yahoo.fr

1 Laboratoire de Rhéologie des Fluides Complexes, Université des sciences et de la technologie d'Oran, USTO-MB, 31000 Oran, Algeria

2 Laboratoire de Matériaux, Sols et thermique, Université des Sciences et de la Technologie d'Oran, USTO-MB, 31000 Oran, Algeria initial total storage capacity of Chorfa dam (samples of this study were collected from this dam) was 70.21 million $\mathrm{m}^{3}$ in 1977 and it was less than 45.80 million $^{3}$ in 2015 (National Agency of Dams and transfers ANBT 2016). The dam is located in mountainous region where climate factors such as rain, frost and wind cause soil erosion and the heavy runoff ensures the transport of sediments to downstream of dam. In addition, the internal erosion phenomena occur frequently in this region. Therefore, it is necessary to study the mechanical behavior and the rheological properties of these sediments to get a better understanding of fine sediment transport dynamics in the dam and to suggest a solution for the problems of siltation. Numerous mathematical models were established to describe the rheological behavior of non-Newtonian fluids. In the following, we present the widely used models. The models of Ostwald-de Waele (Reiner 1926) and Bingham (1922), both of them have two adjustable parameters:

- The model of Ostwald-de Waele (Reiner 1926) is expressed as follows: 


$$
\tau=k \cdot \dot{\gamma}^{n}
$$

where $k$ is the flow consistency index, $n$ is the flow behavior index;

- The Bingham model (Bingham 1922) is expressed as follows:

$\tau=\tau_{0}+\eta_{B} \cdot \dot{\gamma}^{n}$

where $\tau_{0}$ is the yield stress, $\eta_{\mathrm{B}}$ is the plastic viscosity independent of the shear rate, $n$ is the flow behavior index.

There are several rheological models involving three or more adjustable parameters. It is needed to include a third parameter to describe the flow of fluids at low and high shear rates.

- The Herschel-Bulkley model corrects this failure by replacing the term plastic viscosity in the Bingham model with a power law expression (Herschel and Bulkley 1926) as follows:

$$
\tau=\tau_{0}+k \cdot \dot{\gamma}^{n}
$$

- Moreover, Casson equation is generally used to express the non-Newtonian behavior of sediments and activated sludges (Casson 1959):

$$
\tau^{1 / 2}=\tau_{0}^{1 / 2}+\eta_{\infty}^{1 / 2} \dot{\gamma}^{1 / 2}
$$

- The Sisko model is another model which includes three parameters to describe the fluid flow at low and high shear rates (Sisko 1958):

$$
\eta=\eta_{\infty}+k \cdot \dot{\gamma}^{n}
$$

- There are also models with four parameters, who can be used over the full range of shear rates, like the Carreau model. These models are mainly used for food and beverages (Steffe 1996) and blood flow (Shibeshi and Collins 2005).

$$
\frac{\eta-\eta_{\infty}}{\eta_{0}-\eta_{\infty}}=\left(1+(\lambda \gamma)^{a}\right)^{\frac{n-1}{a}}
$$

$a$ is the index that describes the transition between low shear rate as a Newtonian fluid and high shear rate as a power-law fluid; $\lambda$ is a time constant.

But on the other hand, the models with four parameters can be difficult to apply because there is not enough data to get the best fit between model and experimental data. Guibaud et al. (2004) and Baudez et al. (2004) found that the Herschel-Bulkley model could be suitable for describing the viscosity of activated sludge at high concentrations.
Furthermore, Bingham's model was used for characterizing low concentrated sludge. Hasar et al. (2004), Laera et al. (2007) and Pollice et al. (2007) showed that the power law model was the best to describe the viscosity of activated sludge for a low shear rate range. Many studies have been developed to establish a rheological model suitable for all parameters of sludge (Seyssiecq et al. 2008). But so far, there is not a best rheological model having the exactitude to describe the complex properties of all fine sediments and sludge. All these previous models remain empirical.

The main objective of this study was to define the rheological properties of samples taken upstream of the Chorfa dam, to estimate the best rheological model adapted to experimental data, and to determine the correlation between rheological parameters and sludge solids concentration.

\section{Materials and Methods}

\section{Characteristics of the site}

The Chorfa dam (Fig. 1) is located $71 \mathrm{~km}$ north of Mascara (Algeria). It was built upstream from the old dam in 1977. It is intended to irrigate the agricultural perimeters of Mascara's plain (Algeria), (source: National Agency of Dams and transfers ANBT 2003).

The research was carried out on samples taken at the upstream of Chorfa dam, from three meters near the wall, by the Clamshell bucket technique (Fig. 2).

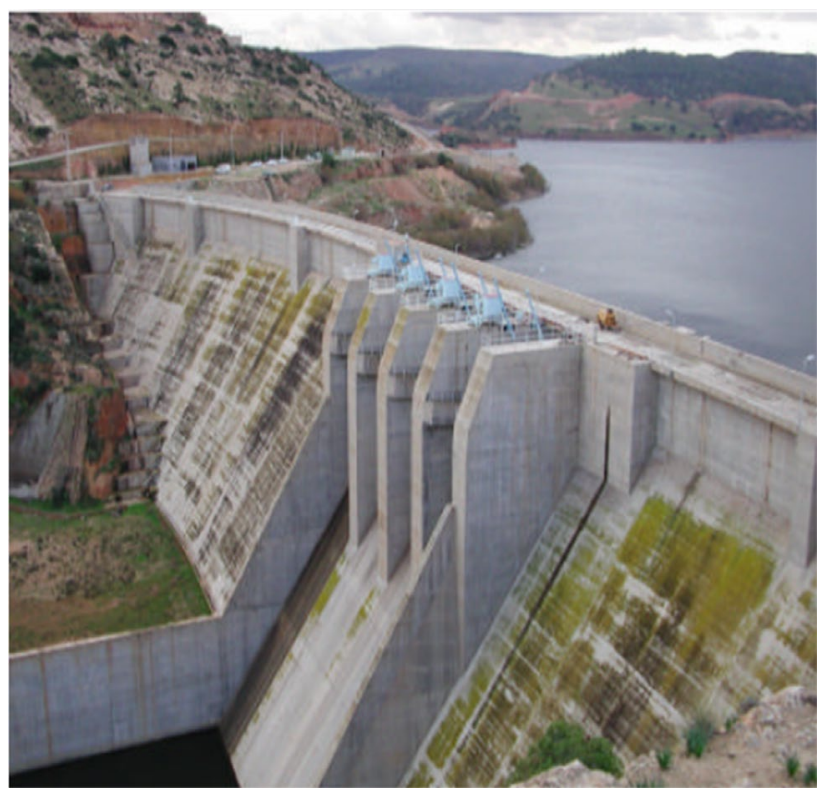

Fig. 1 Chorfa dam (region of Mascara, Algeria). (Source: National Agency of Dams and transfers ANBT 2003) 


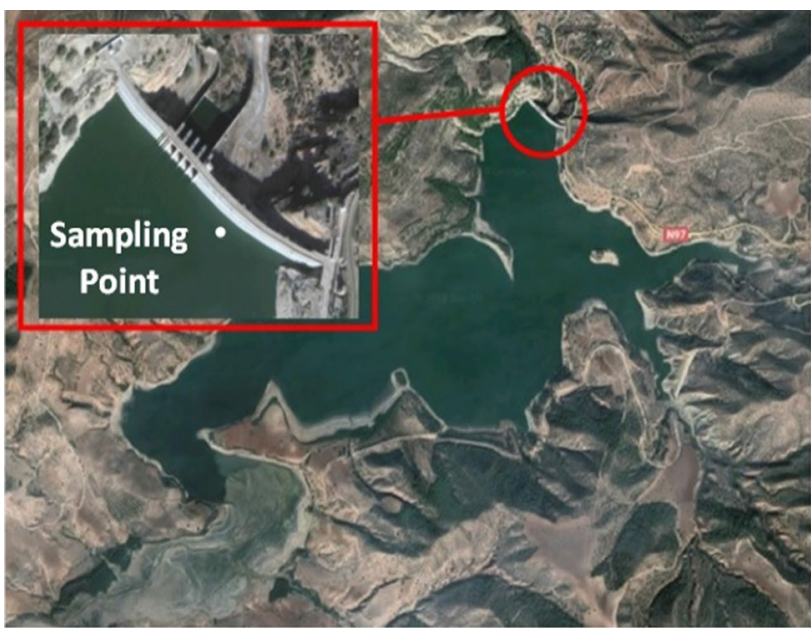

Fig. 2 Location of the samples taken at the upstream of the Chorfa dam

\section{Identification of mud characteristics}

\section{Physical characterization}

Figure 3 shows the particle size distributions of mud samples which are composed mainly of $21 \%$ of fine sand, $45 \%$ of silt and $34 \%$ of clay.

The physical properties of the sediment have been determined and are summarized in Table 1.

Depending on results obtained from the physical analyzes, the sediments of the Chorfa dam are found to be fine grained soil composed mainly of clay, fine sand and silt. According to Casagrande's abacus, the samples are classified as a clay loam soil. All the physical and geotechnical analysis were carried out at the materials, soil and thermal

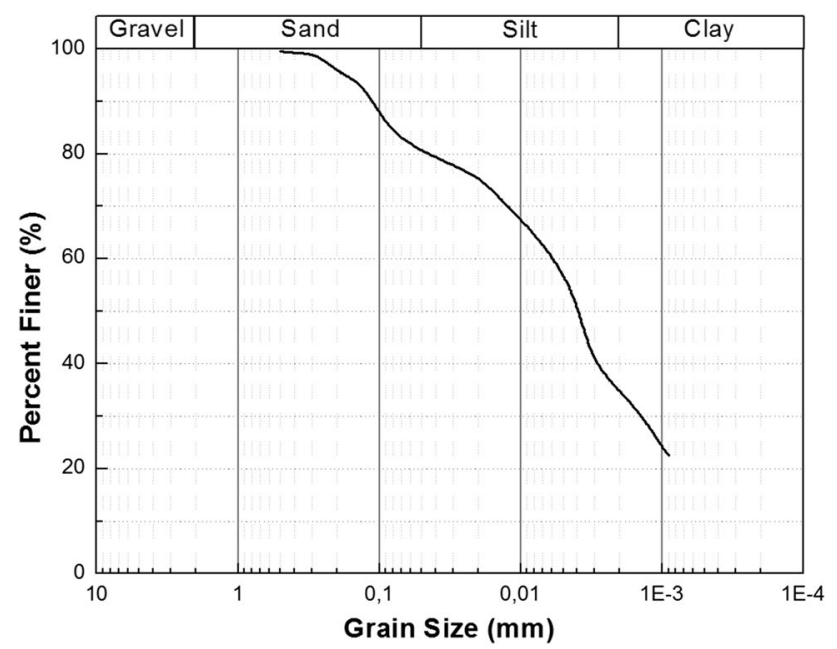

Fig. 3 Particle size distributions for Chorfa dam mud
Table 1 Physical characteristics of the mud

\begin{tabular}{ll}
\hline Parameters & Value \\
\hline Dry density $\gamma_{\mathrm{d}}\left(\mathrm{g} / \mathrm{cm}^{3}\right)$ & 2.65 \\
Water content natural $(\%)$ & 52.33 \\
Liquid limit $W_{\mathrm{L}}(\%)$ & 58.93 \\
Plastic limit $W_{\mathrm{P}}(\%)$ & 35.86 \\
Plasticity index $I_{\mathrm{P}}(\%)$ & 23.07 \\
Consistency index $I_{\mathrm{c}}(\%)$ & 0.28 \\
Methylene blue value MBV (g/100 g of soil) & 5.41 \\
Organic matter OM $(\%)$ & 7 \\
\hline
\end{tabular}

laboratory at the University of Science and Technology of Oran, "Algeria."

\section{Mineralogical characterization}

The mineralogical characteristics of the mud are determined by the XRD method in the Analysis and Application of Radiation Laboratory at the University of Science and Technology of Oran, "Algeria," and are shown in Fig. 4.

The X-ray diffraction analysis of the mud in its natural state (Fig. 4) shows the existence of high quantity of silica $\left(\mathrm{SiO}_{2}\right)$ and calcite $\left(\mathrm{CaCO}_{3}\right)$, a small amount of kaolinite $\left(\mathrm{Al}_{2} \mathrm{O}_{3} 2 \mathrm{SiO}_{2} 2 \mathrm{H}_{2} \mathrm{O}\right)$, illite and also dolomite $\mathrm{CaMg}\left(\mathrm{CO}_{3}\right)_{2}$.

\section{Chemical characterization}

The chemical characteristics were performed on powdered product of mud, less than 100 micrometers and were determined by X-ray fluorescence (XRF) in the Laboratory of Materials Chemistry, Catalysis and Environment at the University of Science and Technology of Oran, "Algeria." The results are summarized in Table 2.

Results of chemical analysis (Table 2) show that the Chorfa dam mud contained a large percent of silica in order of $45.64 \%$, and alumina in order of $43.77 \%$. These two oxides confirm the mineralogical analysis of the mud and the existence of kaolinite and illite with the presence of potassium oxide in order of $2.76 \%$. The percent of loss on ignition is significant, in order of $18.23 \%$ which confirms the presence of organic matter in sediments. The percent of $\mathrm{CaO}(12.67 \%)$ and $\mathrm{MgO}$ (2.33) confirms the presence of carbonates such as calcite $\mathrm{CaCo}_{3}$ and dolomite $\mathrm{CaMg}\left(\mathrm{Co}_{3}\right)_{2}$.

\section{Rheological characterization}

Materials All rheological tests were carried out in the Rheology of Complex Fluids Laboratory at the University of Science and Technology of Oran "Algeria." In this experiment, every sample was diluted with purified water to total solids concentration of $5 \%, 10.5 \%, 15.6 \%, 22.7 \%, 26.8 \%$ 
Fig. 4 X-ray diffractogram of natural mud

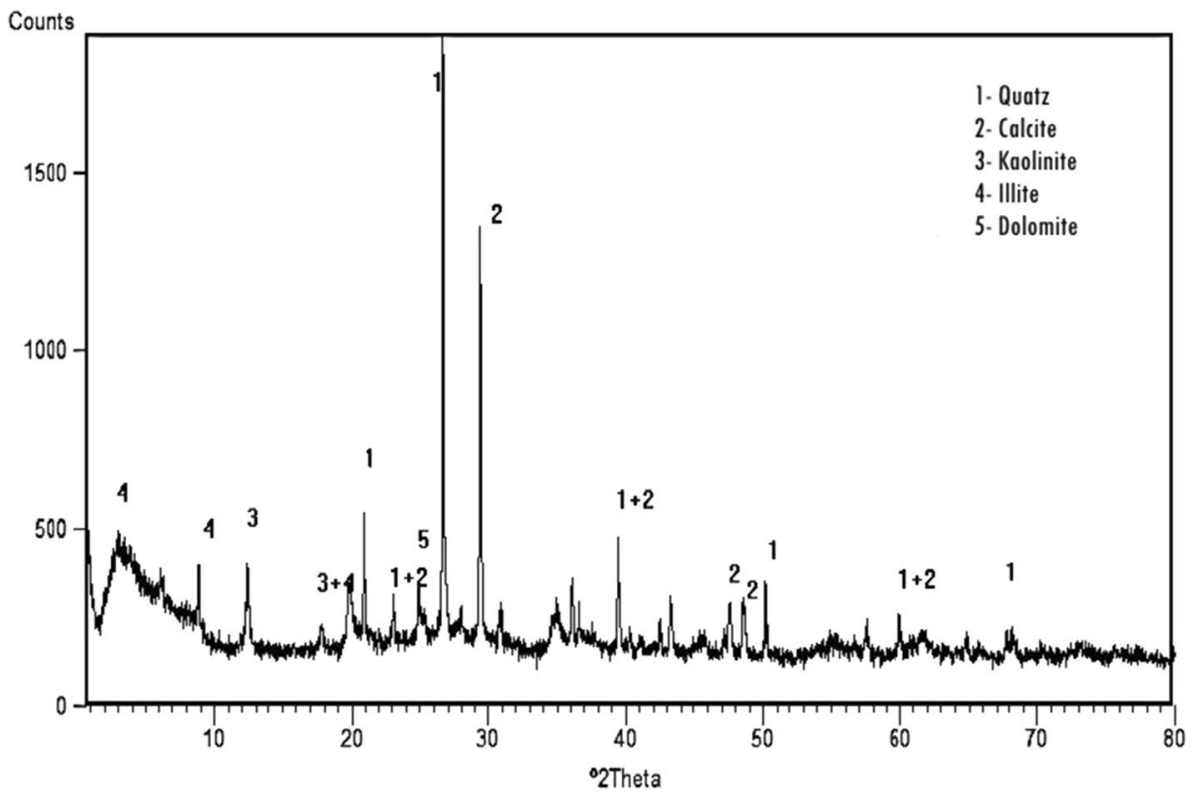

Table 2 Chemical composition of the mud

\begin{tabular}{llllllllll}
\hline Elements & $\mathrm{SiO}_{2}$ & $\mathrm{Al}_{2} \mathrm{O}_{3}$ & $\mathrm{CaO}$ & $\mathrm{Cl}$ & $\mathrm{Fe}_{2} \mathrm{O}_{3}$ & $\mathrm{MgO}$ & $\mathrm{K}_{2} \mathrm{O}$ & $\mathrm{Na}_{2} \mathrm{O}$ & $($ LOI$)$ \\
\hline Quantity (\%) & 45.64 & 11.08 & 12.67 & 0.18 & 6.38 & 2.33 & 2.76 & 0.37 & 18.23 \\
\hline
\end{tabular}

LOI Loss on ignition

and $32.5 \%$. The concentrations were empirically chosen to get the same range of solids concentration used during dam dredging. Then, all mixtures were stirred thoroughly for $24 \mathrm{~h}$ until a sufficiently homogeneous material was obtained. Further, the resulting mixture was left standing for $1 \mathrm{~h}$, then stirred lightly for $5 \mathrm{~min}$ before placing the sample under the measurement geometry.

Rheological measurements The Engler viscometer was used in this work to determine the critical solids concentration $\left(C_{\mathrm{s}}^{*}\right)$ of the Chorfa dam mud. The rheological analysis was carried out using a coaxial cylinder rheometer (Haake RS600) which was equipped with a measuring rotor system and with an inner diameter of $22.80 \mathrm{~mm}$ and an outer diameter of $24.80 \mathrm{~mm}$. A shear rate range was $0-160 \mathrm{~s}^{-1}$, and temperature was fixed at $20{ }^{\circ} \mathrm{C}$.

\section{Results and discussion}

\section{Determination of critical solids concentration of mud}

The variation of zero-shear viscosity $\left(\eta_{0}\right)$ as a function of solids concentration $\left(C_{\mathrm{s}}\right)$ is plotted in Fig. 5. In order to determine the point of the critical solids concentration $\left(C_{\mathrm{s}}^{*}\right)$, the intersection of the two regression lines for low

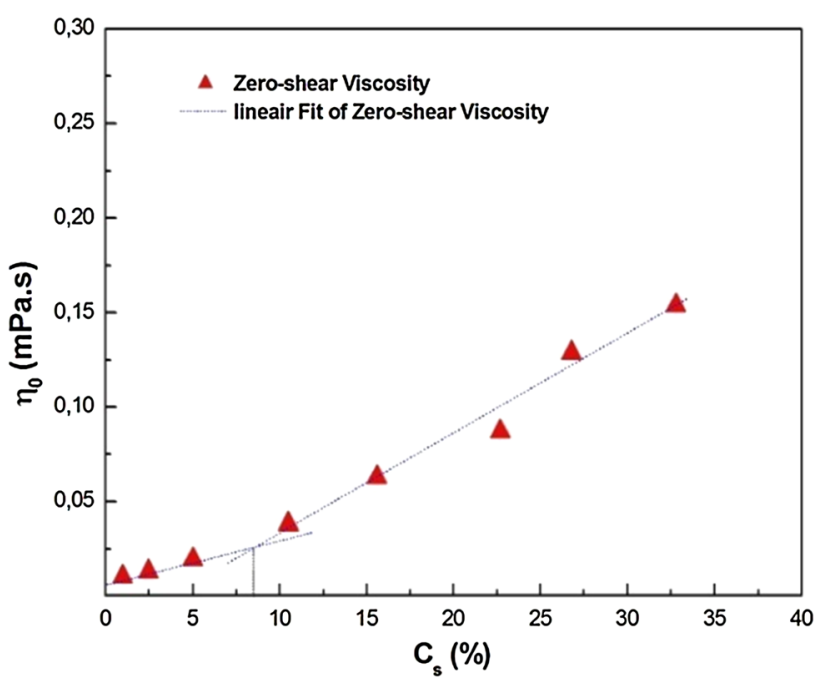

Fig. 5 Zero-shear viscosity $\left(\eta_{0}\right)$ as a function of solids concentration

and high ranges of solids concentration was calculated and a critical value of $8.46 \%$ was obtained (Fig. 5). So the two parts of zero-shear viscosity $\left(\eta_{0}\right)$ can be separated at around $8.46 \%$. Below this concentration, zero-shear viscosity $\left(\eta_{0}\right)$ increases linearly with increasing solids concentration. Above value of $8.46 \%$, zero-shear viscosity $\left(\eta_{0}\right)$ increases drastically. 


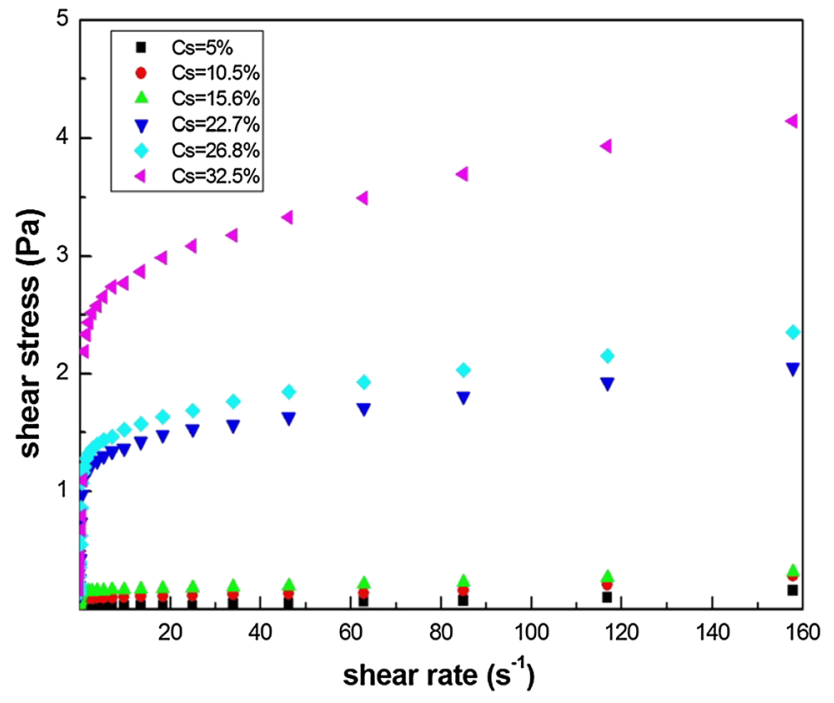

Fig. 6 Shear stress as a function of shear rate at different solids concentrations

\section{Effect of solids concentration on mud rheology}

The effect of solids concentration on mud rheology is important, and diverse ranges of solids concentrations can lead to different types of rheograms. Figure 6 shows rheograms for solids concentration of 5\%, 10.5\%, 15.6\%, $22.7 \%, 26.8 \%$ and $32.5 \%$, in an ambient temperature of $20{ }^{\circ} \mathrm{C}$.

As depicted in Fig. 6, the relationship between shear stress and shear rate is linear for sample which has solids concentration of 5\% and mud behaves as a Newtonian fluid. On the other hand, shear stress-shear rate relationship is nonlinear for all.

Other samples certified that mud samples behave as non-Newtonian fluid, for solids concentration $\left(C_{\mathrm{s}}\right)$ greater than the critical solids concentration $\left(C_{\mathrm{s}}^{*}\right)$. Moreover, the shear stress increased with the increase in solids concentration, and the increment in shear stress was higher with higher mud solids concentration. This is probably due to a smaller distance between particles in a denser sample which produces a large attraction of particles to each other. A shearing force has to be exerted on the mud to decrease the internal friction among the particles forming flocs and to make it flow again. Once the mud flows, the flocs are broken down and the water blended within them is progressively released with increasing shear rate, which facilitates the mud flow and leads to decrease in the viscosity of fluid. This is similar to previous research (Seyssiecq et al. 2008; Baroutian et al. 2013; Liu et al. 2012). According to Seyssiecq et al. (2008), who stated that, a strong interaction between particles got closer to each other and form flocs. This is also interpreted by Baroutian et al. (2013) that the content of polysaccharide and protein increased with increasing solid contents sludge, which was significant for rheological behavior.

\section{Effect of solids concentration on viscosity}

The apparent viscosity as a function of shear rate at solids concentration of 5\%,10.5\%, 15.6\%, 22.7\%, 26.8\% and $32.5 \%$ is shown in Fig. 7.

The viscosity decreased with increase in the shear rate, and the increment in viscosity was higher with higher mud solids concentration. This was also interpreted by Cheng who stated that the increase in apparent viscosity with the increase in solids concentration can be attributed to the increase in the interactions between particles in the fluid, and the low attraction between a large particle leads to forming flocs and aggregates (Cheng 1980).

It is noted in Fig. 9 that for a given solids concentration, in the first zone, the viscosity decreases rapidly at low shear rates $\left(\dot{\gamma}<1.2 \mathrm{~s}^{-1}\right)$, and in the second zone, the viscosity reaches a stable phase at high shear rates. The first zone dominated by the yield shear stress is a phase in which the material flowed before reaching the second zone and dominated by plastic viscosity (Slatter 2006). The viscosity becomes lower at the high shear rates which corresponds to the infinite viscosity of Sisko $\left(\eta_{\infty}\right)$. It is $1 \mathrm{~Pa} \mathrm{~s}$ at $5 \%$ and $20 \mathrm{~Pa} \mathrm{~s}$ at $32.5 \%$. Furthermore, it was observed that the samples have been a shear thinning behavior in the region of low shear rate. This is similar to results obtained by Olhero and Ferreira from the experiments carried out on fine silica powder of average size $19 \mu \mathrm{m}$ (Olhero and Ferreira 2004).

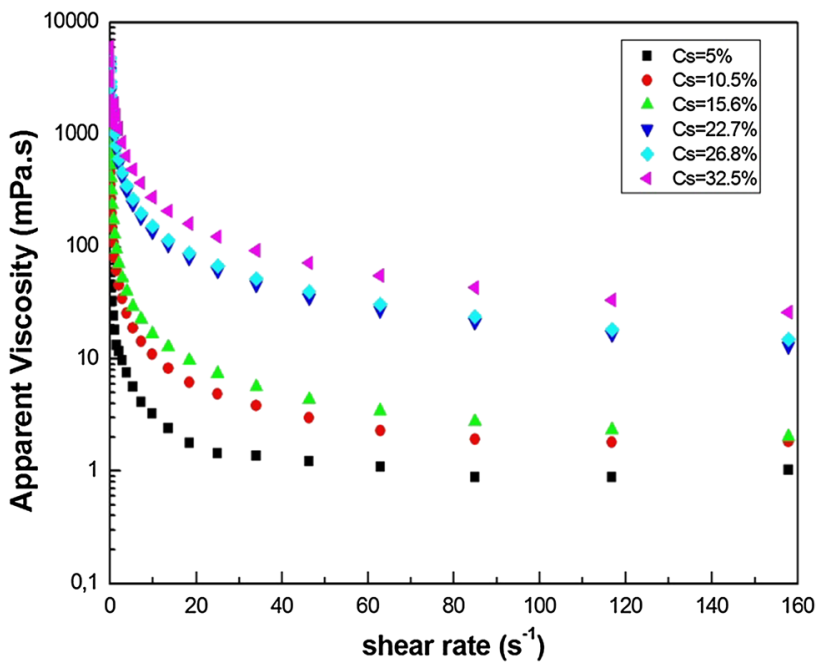

Fig. 7 Apparent viscosity as a function of shear rate at different solids concentrations 


\section{Modeling and correlation of parameters}

In order to suggest the most suitable model for experimental data, four main rheological models (Herschel-Bulkley model, Ostwald-de Waele (power law) model, Bingham model and Casson model) were used for fitting. Table 3 summarizes the adjustment parameters of the four rheological models and the coefficient of determination $\left(R^{2}\right)$ for the different solids concentrations studied in this work. As an example, Figs. 8 and 9 show, respectively, the fitting rheograms by four rheological models for solids concentrations of $5.0 \%$ and $32.5 \%$. According to the value of $\left(R^{2}\right)$, all the rheological models show a better correlation between the experimental data and the fitting results for a solids concentration $\left(C_{\mathrm{s}}\right)$ less than the critical solids concentration $\left(C_{\mathrm{s}}^{*}=8.46 \%\right)$. Moreover, the coefficient of determination $\left(R^{2}\right)$ is higher than $96 \%$ for all models. While for a solids concentration $\left(C_{\mathrm{s}}\right)$ greater than $8.46 \%$, all models showed a variation in $\left(R^{2}\right)$. The coefficient of determination $\left(R^{2}\right)$ decreases slightly in Herschel-Bulkley model $\left(R^{2}=0.9639-0.9014\right.$ for $\left.C_{\mathrm{s}}=5-32.5 \%\right)$ and in power law model $\left(R^{2}=0.9628-0.8703\right.$ for $\left.C_{\mathrm{s}}=5-32.5 \%\right)$. On the other hand, $\left(R^{2}\right)$ decreases rapidly in Bingham and Casson models (for Bingham model $\left(R^{2}=0.9736-0.4708\right.$ for $\left.C_{\mathrm{s}}=5-32.5 \%\right)$ and for Casson model $\left(R^{2}=0.9782-0.6788\right.$ for $\left.\left.C_{\mathrm{s}}=5-32.5 \%\right)\right)$.

Thus, the Herschel-Bulkley model present a good fitting with experimental data and in this model, the value of $\left(R^{2}\right)$ was greater. But on the other hand, the value of $\tau_{0}$ using Herschel-Bulkley model for $C_{\mathrm{s}}=26.8 \%$ was negative $\left(\tau_{0}=-0.7642 \mathrm{~Pa}\right.$ for $\left.C_{\mathrm{s}}=26.8 \%\right)$, which is physically impossible. As a result, the Herschel-Bulkley model is not suitable for all solids concentrations. Therefore, the power law model was the best fitting for all range of solids concentration of mud, followed by the Herschel-Bulkley model. The Bingham and Casson models were also suitable but with less precision.

Using power law model, the fitting results revealed that Chorfa dam mud showed shear thinning behavior because the flow behavior index values $(n)$ were less than 1 (Table 3) for all range of solids concentrations (using power law model, $n=0.97$ for $C_{\mathrm{s}}=5 \%$ and $n=0.23$ for $\left.C_{\mathrm{s}}=32.5 \%\right)$, and the consistency index $(k)$ increased with the increasing solids concentration. This suggested that, with the decrease in solids concentration, mud samples performed more like a Newtonian fluid and the coefficient of determination coefficients $\left(R^{2}\right)$ reduced with decline in solids concentration.

\section{Conclusion}

The physical, chemical, mineralogical and rheological characteristics of Chorfa dam sludge have been studied in this work.

- The geotechnical study showed that the samples studied composed a large proportion of clay and silt and were classified as a clay loam soil.

- Both chemical and mineralogical analyses indicated that mud samples are composed of a clay phase, mostly silica, calcite and other minerals.

- The rheological characteristics were investigated for mud samples from Chorfa dam with solids concentration of $5 \%, 10.5 \%, 15.6 \%, 22.7 \%, 26.8 \%$ and $32.5 \%$ at an ambient temperature of $20^{\circ} \mathrm{C}$.
Table 3 Parameters of different rheological models with different solids concentrations and coefficient of determination

\begin{tabular}{|c|c|c|c|c|c|c|c|}
\hline \multirow[t]{2}{*}{ Model } & \multicolumn{7}{|c|}{ Parameters } \\
\hline & $C_{\mathrm{s}}(\%)$ & 5 & 10.5 & 15.6 & 22.7 & 26.8 & 32.5 \\
\hline \multirow[t]{3}{*}{ Power law } & $k$ & 0.0144 & 0.0849 & 0.1273 & 0.8199 & 0.7994 & 1.4715 \\
\hline & $n$ & 0.9737 & 0.2695 & 0.1354 & 0.1914 & 0.2262 & 0.2358 \\
\hline & $R^{2}$ & 0.9628 & 0.8664 & 0.8665 & 0.8879 & 0.8855 & 0.8703 \\
\hline \multirow[t]{4}{*}{ Herschel-Bulkley } & $\tau_{0}$ & 0.0194 & 0.0406 & 0.0442 & 0.1218 & -0.7642 & 0.1656 \\
\hline & $k$ & 0.0032 & 0.0167 & 0.031 & 0.7578 & 0.8722 & 16,741 \\
\hline & $n$ & 0.9281 & 0.6586 & 0.4278 & 0.188 & 0.1743 & 0.17 \\
\hline & $R^{2}$ & 0.9639 & 0.8664 & 0.8709 & 0.8898 & 0.913 & 0.9014 \\
\hline \multirow[t]{3}{*}{ Bingham } & $\tau_{0}$ & 0.0196 & 0.082 & 0.151 & 14,224 & 16,171 & 29,388 \\
\hline & $\eta_{\mathrm{B}}$ & 0.0008 & 0.0012 & 0.001 & 0.0042 & 0.0164 & 0.0079 \\
\hline & $R^{2}$ & 0.9736 & 0.8664 & 0.6739 & 0.4737 & 0.4988 & 0.4708 \\
\hline \multirow[t]{3}{*}{ Casson } & $\tau_{0}$ & 0.0111 & 0.0717 & 0.1217 & 11,686 & 10,141 & 23,195 \\
\hline & $\eta_{\infty}$ & 0.00042 & 0.00021 & 0.00022 & 0.00082 & 0.00452 & 0.00182 \\
\hline & $R^{2}$ & 0.9782 & 0.847 & 0.8411 & 0.8316 & 0.7518 & 0.6788 \\
\hline
\end{tabular}

$C_{\mathrm{s}}$ mud solids concentrations, $k$ consistency index, $n$ flow behavior index $R^{2}$ coefficient of determination, $\eta$ apparent viscosity, $\eta_{0}$ zero-shear viscosity, $\tau_{0}$ yield stress 


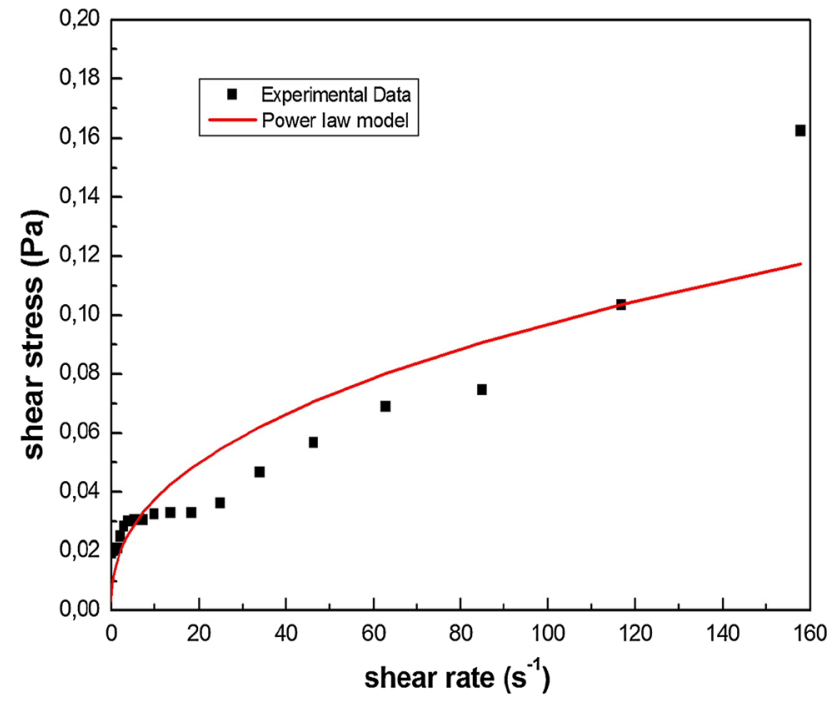

(a)

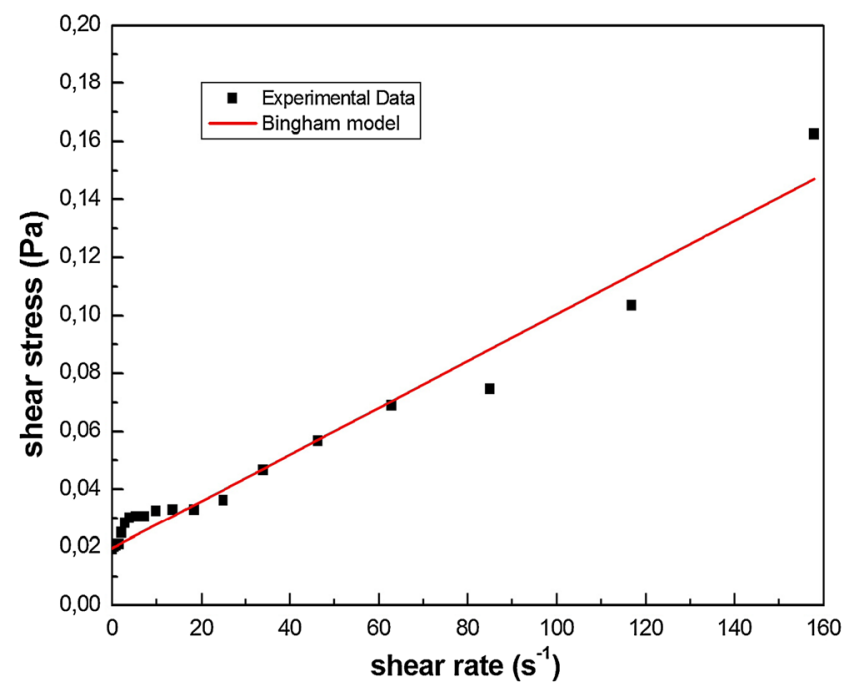

(c)

Fig. 8 Rheological data of mud for $C_{\mathrm{s}}=5.0 \%$ and model constants calculation. a Power law model fitting $\left(k=0.0144 ; n=0.4137 ; R^{2}=0.9628\right)$. b Herschel-Bulkley model fit-

First, it is found that for a solids concentrations $\left(C_{\mathrm{s}}\right)$ less than the critical solids concentrations $\left(C_{\mathrm{s}}^{*}=8.46 \%\right)$, the mud samples showed the Newtonian behavior and the variation of the shear stress with the shear rate are linear. On the other hand, the mud samples showed the shear thinning behavior for solids concentrations $\left(C_{\mathrm{s}}\right)$ greater than the critical solids concentrations $\left(C_{\mathrm{s}}^{*}\right)$ and the shear stress-shear rate relationship is nonlinear. In addition to this, the apparent viscosity increases with the increase in the solids concentration, but for a given

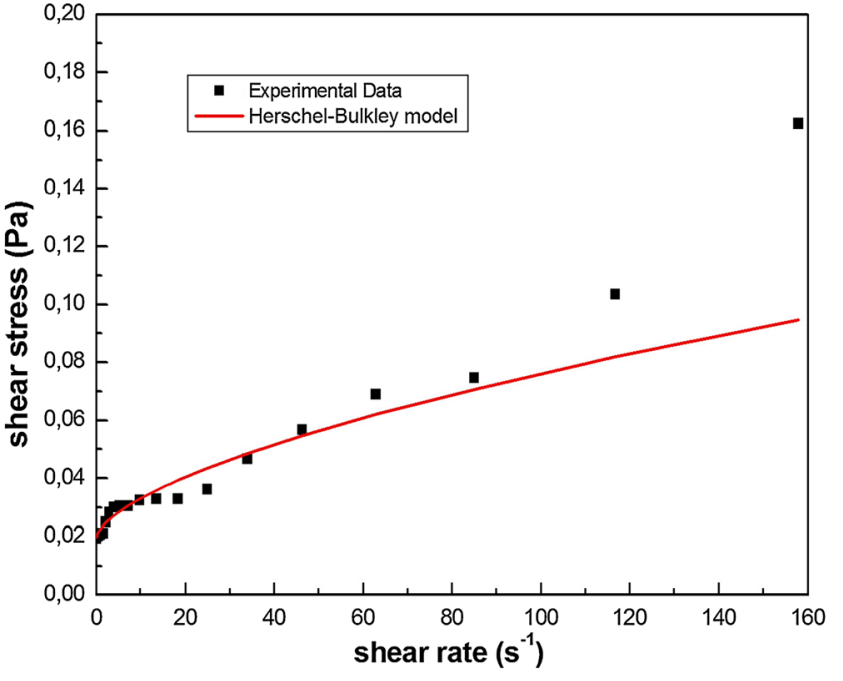

(b)

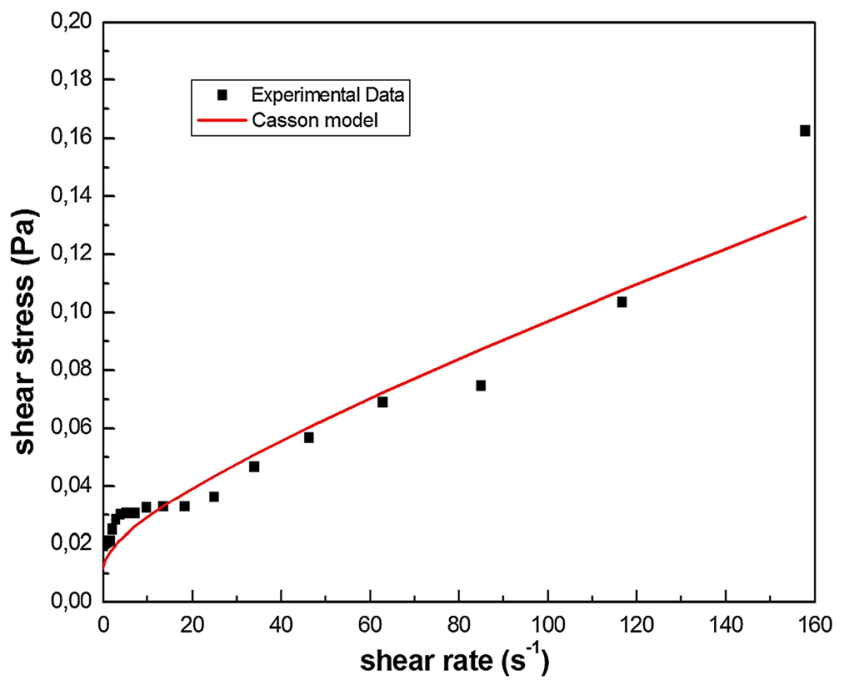

(d)

ting $\left(\tau_{0}=0.0194 ; k=0.0032 ; n=0.6281 ; R^{2}=0.9639\right)$. c Bingham model fitting $\left(\tau_{0}=0,0196 ; \mu_{\mathrm{B}}=0.0008 ; R^{2}=0.9736\right)$. d Casson model fitting $\left.\left(\tau_{0}=0.0111 ; \mu_{0}=0.00042\right)^{2}, R^{2}=0.9782\right)$

solids concentration, the apparent viscosity decreases with increasing shear rate, which explains the shear thinning behavior of the Chorfa dam mud.

Finally, fitting results of four rheological models (Bingham Plastic Model, Ostwald-de Waele (power law), Herschel-Bulkley and Casson) to the experimental rheological data of mud samples revealed that the Ostwald-de Waele (power law) model was the best fitting for all range of solids concentration.

Acknowledgements The authors gratefully thank the Vice Chancellor and Research Coordinator of University of Science and Technology of Oran, "Algeria," for their unfailing support of research and their 


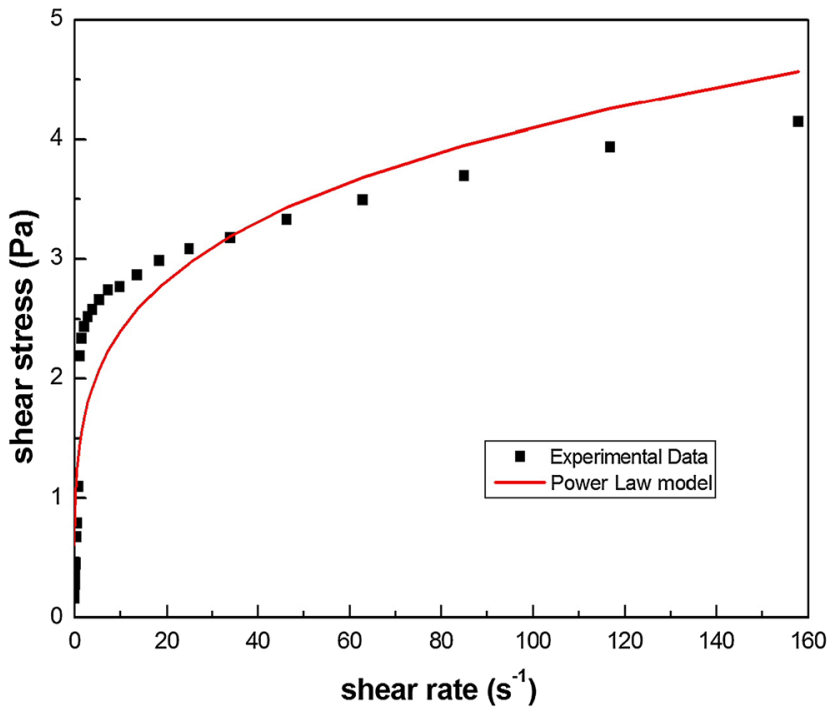

(a)

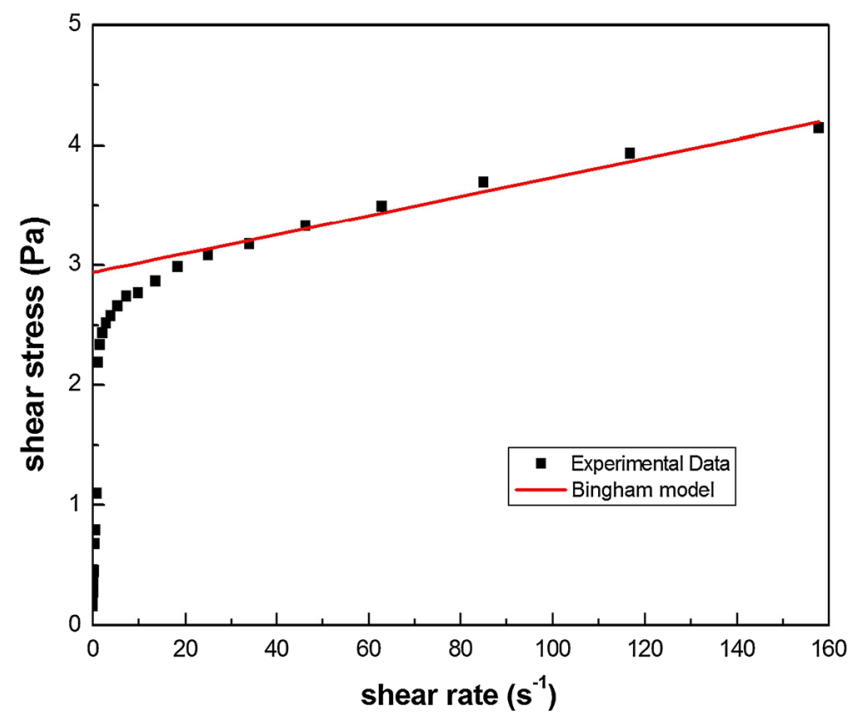

(c)

Fig. 9 Rheological data of mud for $C_{\mathrm{s}}=32.5 \%$ and model constants calculations. a Power law model fitting $\left(k=1.4715 ; n=0,2358 ; R^{2}=0.8703\right)$. b Herschel-Bulkley model

encouragement of collaboration between laboratories of the university to develop the scientific research.

Open Access This article is distributed under the terms of the Creative Commons Attribution 4.0 International License (http://creativeco mmons.org/licenses/by/4.0/), which permits unrestricted use, distribution, and reproduction in any medium, provided you give appropriate credit to the original author(s) and the source, provide a link to the Creative Commons license, and indicate if changes were made.

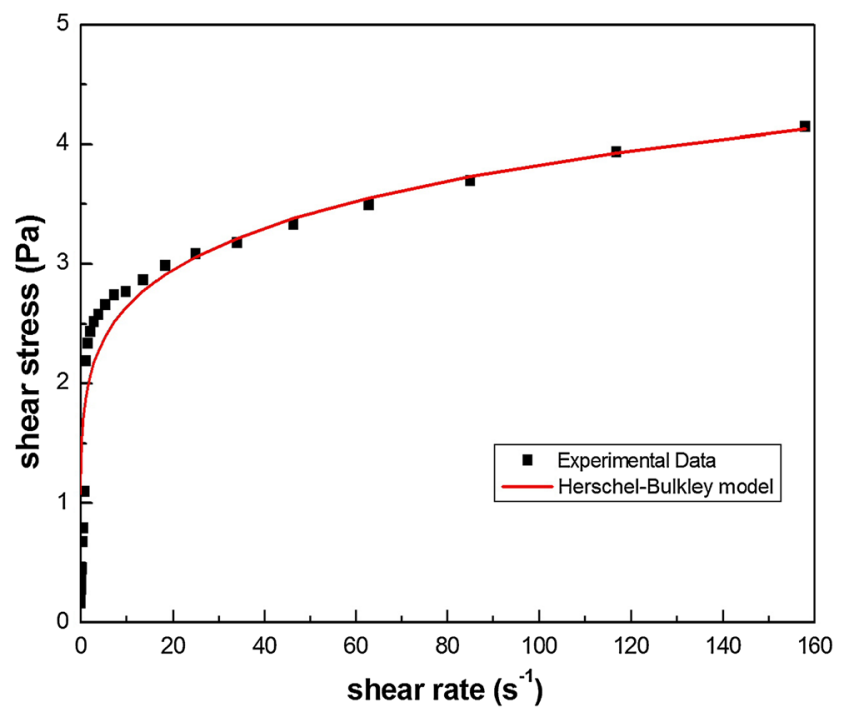

(b)

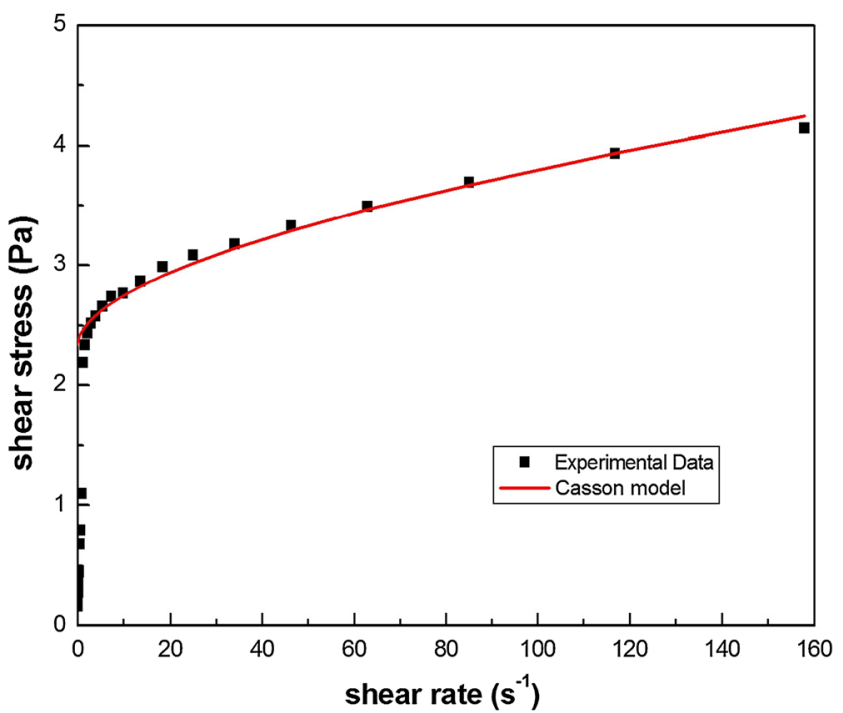

(d)

fitting $\left(\tau_{0}=0.1656 ; k=1.6741 ; n=0.1700 ; R^{2}=0.9014\right)$. c Bingham model fitting $\left(\tau_{0}=2.9388 ; \mu_{B}=0.0079 ; R^{2}=0.4708\right)$. d Casson model fitting $\left.\left(\tau_{0}=2.3195 ; \mu_{0}=0.00182\right)^{2}, R^{2}=0.6788\right)$

\section{References}

Baroutian S, Eshtiaghi N, Gapes DJ (2013) Rheology of a primary and secondary sewage sludge mixture: dependency on temperature and solid concentration. Biores Technol 140:227-233

Baudez JC, Ayol A, Coussot P (2004) Practical determination of the rheological behavior of pasty biosolids. J Environ Manag 72(3): 181-188

Bingham EC (1922) Fluidity and plasticity, vol 2. McGraw-Hill, New York

Casson N (1959) Rheology of disperse systems. Pergamon Press, London, $\mathrm{p} 84$

Cheng DCH (1980) Viscosity-concentration equations and flow curves for suspensions. Chem Ind 10:403-406 
Guibaud G, Dollet P, Tixier N, Dagot C, Baudu M (2004) characterisation of the evolution of activated sludges using rheological measurements. Process Biochem 39(11):1803-1810

Hasar H, Kinaci C, Ünlü A, Toğrul H, Ipek U (2004) Rheological properties of activated sludge in a sMBR. Biochem Eng $\mathrm{J}$ 20(1):1-6

Herschel WH, Bulkley R (1926) Konsistenzmessungen von gummibenzollösungen. Colloid Polym Sci 39(4):291-300

Laera G, Giordano C, Pollice A, Saturno D, Mininni G (2007) Membrane bioreactor sludge rheology at different solid retention times. Water Res 41(18):4197-4203

Liu JZ, Wang RK, Gao FY, Zhou JH, Cen KF (2012) Rheology and thixotropic properties of slurry fuel prepared using municipal wastewater sludge and coal. Chem Eng Sci 76:1-8

National Agency of Dams and transfers ANBT (2003) Détection des fuites d'eau dans les retenues des barrages. Rapport interne. ANBT, Alger

National Agency of Dams and transfers ANBT (2016) Bilan annuel d'exploitation des barrages (1986-2015). ANBT, Alger

Olhero SM, Ferreira JMF (2004) Influence of particle size distribution on rheology and particle packing of silica-based suspensions. Powder Technol 139(1):69-75

Pollice A, Giordano C, Laera G, Saturno D, Mininni G (2007) Physical characteristics of the sludge in a complete retention membrane bioreactor. Water Res 41(8):1832-1840
Reiner M (1926) Ueber die Strömung einer elastischen Flüssigkeit durch eine Kapillare. Kolloid-Zeitschrift 39(1):80-87

Remini B, Avenard JM (1998) Evolution de l'envasement dans la retenue du barrage de Foum El Gherza. Bull Réseau Eros 18:98-105

Seyssiecq I, Marrot B, Djerroud D, Roche N (2008) In situ triphasic rheological characterisation of activated sludge, in an aerated bioreactor. Chem Eng J 142(1):40-47

Shibeshi SS, Collins WE (2005) The rheology of blood flow in a branched arterial system. Appl Rheol 15(6):398

Sisko AW (1958) The flow of lubricating greases. Ind Eng Chem 50(12):1789-1792

Slatter P (2006) Plant design for slurry handling. J South Afr Inst Min Metall 106(10):687-691

Steffe JF (1996) Introduction to rheology. Rheol Methods Food Process engineering 2:1-93

Publisher's Note Springer Nature remains neutral with regard to jurisdictional claims in published maps and institutional affiliations. 